\title{
Development of Maize-Tigernut Fortified Weaning Food Using Starter Cultures
}

\author{
Sherifah Monilola Wakil*, Joshua Opeyemi Ola \\ Department of Microbiology, University of Ibadan, Ibadan, Nigeria \\ Email: *shemowak@yahoo.com, *wakilola@gmail.com
}

How to cite this paper: Wakil, S.M. and Ola, J.O. (2018) Development of Maize-Tigernut Fortified Weaning Food Using Starter Cultures. Food and Nutrition Sciences, 9, 1444-1457.

https://doi.org/10.4236/fns.2018.912105

Received: September 13, 2018

Accepted: December 25, 2018

Published: December 28, 2018

Copyright ( $) 2018$ by authors and Scientific Research Publishing Inc. This work is licensed under the Creative Commons Attribution International License (CC BY 4.0).

http://creativecommons.org/licenses/by/4.0/ (c) (i) Open Access

\begin{abstract}
The effects of starter fermentation on the nutritional qualities of maize-tigernut fortified weaning foods were investigated. The dry-milled, malted maize grains fortified with dry-milled roasted tigernut flours (70:30) were subjected to $48 \mathrm{hrs}$ of spontaneous and starter fermentation (singly and as combined starters). Nutritional, sensory characteristics and feeding trials of the weaning foods were evaluated. Four fermented weaning blends were formulated: FMT (spontaneously fermented maize-tigernut), SFMT1 (Lactobacillus plantarum F2C fermented maize-tigernut), SFMT2 (Lactobacillus plantarum U2A fermented maize-tigernut) and SFMT3 (combined starter-fermented maize-tigernut). SFMT2 had the highest crude protein, fat, fibre, ash and least carbohydrate content among the blends. The highest energy content (456.84 $\mathrm{Kcal} / 100 \mathrm{~g}$ ) was observed in blend SMFT2 which was also higher than that of both negative (Nutrend) and positive (Conventional animal feed) controls. The least antinutrient and vitamin contents were recorded in SFMT2. Blend SFMT1 had the highest Vitamin B1 $(0.67 \mathrm{mg} / 100 \mathrm{~g})$, Vitamin A $(472.60$ $\mathrm{ug} / 100 \mathrm{~g})$, phosphorus $(75.45 \mathrm{mg} / 100 \mathrm{~g})$ and zinc $(1.05 \mathrm{mg} / 100 \mathrm{~g})$ contents while the highest calcium $(17.17 \mathrm{mg} / 100 \mathrm{~g})$ and iron $(22.82 \mathrm{mg} / 100 \mathrm{~g})$ were recorded in SFMT2. Sample SFMT2 was rated the highest in all of the sensory characteristics except colour and the highest overall acceptability (6.00) which was not different significantly from all other starter produce blends. Biological evaluation showed blend SFMT2 fed animals having the highest weight by 28 days $(73.14 \mathrm{~g})$, mean weight gain $(5.46 \mathrm{~g})$, mean feed intake $(18.71 \mathrm{~g})$ and mean protein efficiency ratio PER (3.65). However, all the PER values including that of controls (2.30) were higher than the value of 2.10 recommended by the Protein Advisory Group (PAG) for complementary foods. The RBC, WBC and PCV of the trial groups were within the rat hematologic reference ranges. Blend SFMT2 ( $L$. plantarum $\mathrm{U} 2 \mathrm{~A}$ fermented blend) gave the best performance after rat feeding trials.
\end{abstract}




\section{Keywords}

Fortification, Tigernut, Nutritional Evaluation, Biological Evaluation, Starter-Fermentation

\section{Introduction}

The arrival of a new born is accompanied by the secretion of the highly nutritive, thick yellowish pre-milk substance, referred to as colostrum. The colostrum contains the very essential nutrients as well as antibodies and it helps in boosting the immunity of the infant to infections [1] [2] [3] [4]. Breast milk usually provides all the energy, nutrients and fluids that baby needs in order to grow and develop healthily during the first six months of life [5] [6]. Infants when exclusively breastfed for the optimal duration of six months are significantly protected against the major childhood diseases' conditions such as diarrhea, gastrointestinal tract infection, allergic diseases, diabetes, obesity, childhood leukaemia and lymphoma, inflammatory and bowel disease [5] [6].

The breast milk alone remains sufficient for an infant up until the sixth months after birth. Its supply of energy, protein, vitamin A and B6 as well as calcium, meets the requirements of the infant, it is however clear that the breast-milk is insufficient in its supply of vitamin D, iron and zinc [7] [8]. This inadequacy becomes more elaborate after 6 months of birth due to the increase in the nutrient requirements of the infant. There is therefore the need to mitigate the inadequacies with the use of supplements in the mother and child and complementary feeding of the infant if malnutrition occurrence is to be avoided.

The digestibility of the weaning food and the absorption capacity of the gastrointestinal tract are some of the factors that determine how efficient the contributions of the foods are to the overall health, growth and development of the infants [9] [10]. The vast majority of the infants are weaned most times with the low-cost traditional weaning food and weaning practices which resulted in increased susceptibility of infants to infections, mortality and diseases such as kwashiorkor, marasmus, beriberi, rickets and several other protein-energy malnutrition and micro-nutrient under-nutrition [4] [11] [12] [13].

Traditional weaning foods of West Africa are mostly based on the family staple foods which include cereals, starchy tubers, legumes and vegetables [14] [15]. Of these, cereals based weaning foods are mostly utilized and this has been a challenge due to their low-nutritive value, including inadequate quantity of the essential amino acids (lysine and tryptophan) that are important in the infants' growth [16] [17].

There have been several approaches aimed at addressing the challenges associated with the infants' consumption of the traditional weaning foods. These include the use of processing steps such as fermentation, malting, liquefaction, dry-milling, cereal-legume co-fermentation, fortification with selected additives while adhering to guidelines and regulations, addition of sugar and oil to cereal 
gruels as well as hygienic processing [18] [19] [20].

Supplementation of maize with legumes such as cowpea, Bambara-nut and soy-bean, has been reported to contribute significantly to the improvement of the protein content of the cereal based foods [21]-[26]. Tigernut suitability in formulation of weaning food as a result of its high energy, resulting from the rich protein, fat and sugar content, as well as minerals (phosphorus, potassium) and vitamins $\mathrm{C}$ and $\mathrm{E}$ constituents has been reported [27] [28]. Tigernut is gluten and cholesterol free and has very low Sodium Content, making it ideal for infants. There has been an increased awareness for the utilization of tigernut as nutritional source in recent times [29] [30] [31] [32] [33], however, tigernut remains underutilized in weaning food formulations. This work aimed at developing a good quality weaning blend having adequate protein-energy contents, necessary to promote growth and enhance nitrogen retention in infants.

\section{Materials and Methods}

\subsection{Collection of Sample and Starter Organisms}

Suwan-1, a variety of Maize grain (Zea mays) used in this study was obtained from the Institute of Agricultural Research and Training (IAR \& T), Moor plantation, Ibadan, Oyo state, Nigeria. Tigernut (Cyperus esculentus) was purchased from Bodija market, Ibadan, Oyo state, Nigeria.

Pure cultures of Lactobacillus plantarum F2C and Lactobacillus plantarum U2A were obtained from the Industrial and Biotechnology laboratory of the Department of Microbiology, University of Ibadan, Oyo state. The cultures of $L$. plantarum strains were routinely maintained on de Man Rogosa and Sharpe (MRS) agar slant at $4^{\circ} \mathrm{C}$.

\subsection{Sample Processing}

The Maize grains (Zea mays) were sorted manually to remove dirt, stones, broken or moldy grains, washed and steeped in distilled water (1:3 w/v) at ambient temperature for $18 \mathrm{hrs}$. The steeped grains were malted and germination was halted by oven drying at $80^{\circ} \mathrm{C}$ to $10 \%$ moisture. The root and shoot portions were removed and malted grains were dry milled to a fine particle size using a sterile blender (Philips kenwood, UK) followed by sieving to obtain a finer particle size flour.

Tigernut tubers (Cyperus esculentus) were sorted to remove stones, pebbles, dirt, damaged tubers and other extraneous materials followed by thorough washing in series of clean water to remove adhering soils. The cleaned tubers were then drained, dried and roasted in an oven at $85^{\circ} \mathrm{C}$ for $24 \mathrm{hrs}$. The burnt tubers were removed and the rest of the bulk was dry milled into flour and sieved to obtain fine flour.

\subsection{Formulation, Fermentation and Sampling of Composite Blends}

Blend formulation (maize-tigernut in a ratio of 70:30) was carried out by the 
method of Malleshi et al. [34]. The blends in the different flasks were reconstituted with sterile distilled water at a concentration of $30 \%(w / v)$ [35] followed by fermentation.

\section{Fermentation}

The formulation was subjected to spontaneous fermentation at $30^{\circ} \mathrm{C} \pm 2{ }^{\circ} \mathrm{C}$ for 48 hours and also to starter fermentation using $10^{8} \mathrm{cfu} / \mathrm{ml}$ pure cultures of starter singly and in combination [36]. Four fermented weaning blends were formulated: FMT (spontaneously fermented maize-tigernut), SFMT1 (Lactobacillus plantarum F2C fermented maize-tigernut), SFMT2 (Lactobacillus plantarum U2A fermented maize-tigernut) and SFMT3 (combined starter-fermented maize-tigernut). The developed blends were analyzed for their in vitro and in vivo nutritional qualities.

\subsection{Analysis of Fermented Formulations}

\subsubsection{Determination of Proximate Contents}

The proximate analysis of moisture content, crude protein, crude fat, crude fibre and ash were determined by the methods of the Association of Official Analytical Chemists [37] and total carbohydrate was determined by difference. The gross energy density of each formulated blend was determined using the Atwater factor.

$$
\text { Energy value }(\mathrm{KCal} / 100 \mathrm{~g})=(\text { carbohydrate } \times 4)+(\text { fat } \times 9)+(\text { protein } \times 4)
$$

\subsubsection{Determination of Anti-Nutrient Contents}

The anti nutrients that were determined include tannin, oxalate and phytic acid. Tannin content was determined spectrophotometrically by the method of AOAC [38], Oxalate using the method of Sanchez-Alonso and Lachica [39] while percentage phytic acid was determined titrimetrically using the formula described by AOAC [38].

\subsubsection{Determination of Vitamin Contents}

Thiamine (Vitamin B1), riboflavin (Vitamin B2), and (Vitamin A) were determined by the methods of the Association of Official Analytical Chemists [39].

\subsubsection{Determination of Mineral Contents}

The method of the Association of Official Analytical Chemists [38] was used in the determination of the mineral contents. Mineral analysis was carried out by ashing of $5 \mathrm{~g}$ of the sample into white ash at a temperature of $550^{\circ} \mathrm{C}$ in a muffle furnace for 2 hours, followed by acid wash and filtration. The mineral elements (iron, magnesium, calcium, zinc, and phosphorus) were been determined using spectrophotometric methods (Atomic Absorption of Spectrophotometry AAS, 1 Nodel Phillips Pil 9100 X).

\subsubsection{Sensory Evaluation of Formulated Blends}

Sensory attributes of the best four fermented weaning foods were assessed by 15 
untrained panelists of nursing mothers in Kajorepo community, Akinyele local government, Ibadan, Oyo state using the method described by Wakil and Alao [40].

\subsection{Biological Evaluation of Formulated Blends}

Animal feed experiment was carried out using male albino rats (Rattus norvegicus) of weaning age (three to four weeks old and with weight varying between 18 $34 \mathrm{~g}$ ) in order to carry out an assessment of the nutritional quality of the formulated weaning food and the overall health effect of the formulated weaning diet.

The four (4) formulations were used as feeding diet while Nutrend (a commercial weaning food brand) fed treatment group of the albino rats served as a negative control and a group fed with the commercial conventional diets of the rats served as positive control.

\section{Animal Experiment}

Twenty-four (24) young male albino rats of weaning age procured were randomly distributed into groups based on the experimental diet formulations to be used. The animals were kept in standard cages and subjected to the same environmental conditions. Each group comprised of four (4) rats per cage making a total of six (6) experimental groups. The rats were allowed to acclimatize for a period of one week before commencement of feeding with the experimental diets and the trials was carried out within duration of 28 days. Data were collected to determine the feed intake, body weight changes, feed conversion ratio (FCR) and protein efficiency ratio (PER) using the method of Addass et al. [41]. Determination of hematological parameters (RBC, WBC and PCV) was carried out using the method of Bull et al. [42].

\subsection{Statistical Analysis}

All the data obtained were subjected to statistical analysis using analysis of variance (ANOVA) and the mean separated by Duncan's multiple test range using the Gen Stat Software.

\section{Results}

Table 1 shows the proximate analysis of all the weaning diets fed to the experimental animal groups. The least protein (7.95\%) and ash (0.79\%) contents observed were obtained in the experimental weaning diet of group 1 which was fed with spontaneously fermented maize-tigernut blend (FMT) while group 2 weaning diet (SFMT1) had the least (1.40\%) moisture and highest (78.75\%) carbohydrate contents. Proximate analysis of group 3 diet (SFMT2) shows that the experimental diet had the highest (15.21\%) content of crude fat and $456.84 \mathrm{KCal}$ of energy, among the experimental diets. The SFMT2 blend is composed of $3.42 \%$ moisture, $8.39 \%$ crude protein, $15.21 \%$ crude fat, $4.56 \%$ crude fibre, $1.38 \%$ ash and $71.59 \%$ carbohydrate. The proximate contents of the experimental weaning diet for group 4 (SFMT3) had 3.32\% moisture, $8.25 \%$ crude protein, 
Table 1. Proximate analysis of the weaning diets supplied to the albino rats (per $100 \mathrm{~g}$ ).

\begin{tabular}{ccccccccc}
\hline Group & Experimental Diet & Moisture \% & Protein \% & Fat \% & Fibre \% & Ash \% & Carbohydrate \% Energy KCal/100 g \\
\hline 1 & FMT & $6.71 \pm 0.01^{\mathrm{b}+*}$ & $7.95 \pm 0.07^{\mathrm{d}}$ & $9.19 \pm 0.01^{\mathrm{d}}$ & $4.36 \pm 0.03^{\mathrm{d}}$ & $0.79 \pm 0.01^{\mathrm{f}}$ & $75.25 \pm 0.08^{\mathrm{c}}$ & $415.92 \pm 0.12^{\mathrm{d}}$ \\
2 & SFMT1 & $1.40 \pm 0.03^{\mathrm{f}}$ & $8.03 \pm 0.07^{\mathrm{d}}$ & $10.51 \pm 0.01^{\mathrm{c}}$ & $3.78 \pm 0.01^{\mathrm{e}}$ & $1.31 \pm 0.02^{\mathrm{d}}$ & $78.75 \pm 0.13^{\mathrm{a}}$ & $441.68 \pm 0.17^{\mathrm{b}}$ \\
3 & SFMT2 & $3.42 \pm 0.02^{\mathrm{c}}$ & $8.39 \pm 0.07^{\mathrm{c}}$ & $15.21 \pm 0.01^{\mathrm{a}}$ & $4.56 \pm 0.02^{\mathrm{c}}$ & $1.38 \pm 0.01^{\mathrm{c}}$ & $71.59 \pm 0.06^{\mathrm{d}}$ & $456.84 \pm 0.04^{\mathrm{a}}$ \\
4 & SFMT3 & $3.32 \pm 0.01^{\mathrm{d}}$ & $8.25 \pm 0.07^{\mathrm{c}}$ & $10.68 \pm 0.02^{\mathrm{b}}$ & $2.57 \pm 0.02^{\mathrm{f}}$ & $1.25 \pm 0.00^{\mathrm{e}}$ & $76.50 \pm 0.09^{\mathrm{b}}$ & $435.14 \pm 0.06^{\mathrm{c}}$ \\
5 & Nutrend & $2.50 \pm 0.02^{\mathrm{e}}$ & $15.00 \pm 0.02^{\mathrm{a}}$ & $9.00 \pm 0.02^{\mathrm{e}}$ & $7.00 \pm 0.02^{\mathrm{b}}$ & $2.30 \pm 0.02^{\mathrm{b}}$ & $64.20 \pm 0.02^{\mathrm{f}}$ & $398.00 \pm 0.02^{\mathrm{e}}$ \\
6 & CAF & $8.90 \pm 0.01^{\mathrm{a}}$ & $13.98 \pm 0.03^{\mathrm{b}}$ & $5.48 \pm 0.01^{\mathrm{f}}$ & $8.41 \pm 0.01^{\mathrm{a}}$ & $3.20 \pm 0.00^{\mathrm{a}}$ & $68.43 \pm 0.03^{\mathrm{e}}$ & $379.00 \pm 0.08^{\mathrm{f}}$ \\
\hline
\end{tabular}

${ }^{*}$ Mean \pm standard error based on three replicates. ${ }^{+}$Means within the same column with different superscript are significantly different at $\mathrm{P} \leq 0.05$. Key: FMT:- spontaneously fermented maize-tigernut blend, diet supplied to group 1; SFMT1: -maize-tigernut blend fermented using Lactobacillus plantarum F2C supplied to group 2; SFMT2: -maize-tigernut blend fermented using Lactobacillus plantarum U2A supplied to group 3; SFMT3: -maize-tigernut blend fermented using combined starter supplied to group 4; Nutrend: -commercial weaning food (group 5); CAF: -conventional animal feed (group 6).

$10.68 \%$ crude fat, $1.25 \%$ ash, $76.50 \%$ carbohydrate and the least $(2.57 \%)$ content of crude fibre.

Group 5 weaning diet (Nutrend) was observed to contain $2.50 \%$ moisture, $9.00 \%$ fat, $7.00 \%$ fibre, $2.3 \%$ ash, the least $(64.20 \%)$ carbohydrate content and the highest protein content $(15.00 \%)$ among the experimental weaning diets. The proximate composition of the experimental diet for group6 (CAF; conventional animal feed) also revealed to be made up of $8.90 \%$ moisture, $13.98 \%$ crude protein, $5.48 \%$ crude fat, $8.41 \%$ crude fibre, $3.20 \%$ ash and $68.43 \%$ carbohydrate. Among the experimental diets, the weaning diet supply of group six had the highest moisture and ash contents but the least energy content of 379.00 $\mathrm{KCal} / 100$ g. Statistical analysis revealed that differences observed in the moisture, crude fat, ash, carbohydrate and energy contents of all the experimental diets were significantly different at $\mathrm{P} \leq 0.05$. Statistical analysis also showed that FMT and SFMT1, and SFMT2 and SFMT3 diets were not significantly different $(\mathrm{P} \leq 0.05)$ from each other in terms of protein contents but differ significantly from group 5 (CAF) and group 6 (Nutrend) diets.

The unfermented samples (UMT) had the least phytate $(0.226 \%)$ and oxalate $(0.104 \%)$ contents while least tannin content $(0.028 \%)$ was observed for SFMT3 (Table 2). Among the fermented formulated samples, blend fermented using Lactobacillus plantarun U2A (SFMT2) had the least phytate (0.236\%) and oxalate $(0.193 \%)$ contents. Statistical analysis of the antinutrient contents revealed that the antinutrient compositions of the formulations were significantly different $(P \leq 0.05)$ among the blends.

\subsection{Vitamin Composition of the Maize-Tigernut Formulated Blend Samples}

Table 3 shows vitamin A, B1 and B2 contents of the maize-tigernut formulated blends. From the table, the unfermented maize-tigernut blend (UMT) had the least vitamin A, B1 and B2 contents. Among the formulated fermented samples, blend SFMT1 had the highest vitamin A (472.60 $\mu \mathrm{g} / 100 \mathrm{~g})$ and vitamin B1 $(0.67 \mathrm{mg} / 100 \mathrm{~g})$ contents while the least vitamin A, B1 and B2 contents of 460.0 
Table 2. Antinutrient composition (\%) of all formulated blend samples.

\begin{tabular}{cccc}
\hline Sample code & Phytate & Oxalate & Tannin \\
\hline UMT & $0.226 \pm 0.009^{\mathrm{d}}$ & $0.104 \pm 0.002^{\mathrm{e}}$ & $0.042 \pm 0.001^{\mathrm{a}}$ \\
FMT & $0.266 \pm 0.002^{\mathrm{ab}}$ & $0.207 \pm 0.001^{\mathrm{a}}$ & $0.042 \pm 0.001^{\mathrm{a}}$ \\
SFMT1 & $0.262 \pm 0.005^{\mathrm{b}}$ & $0.204 \pm 0.001^{\mathrm{b}}$ & $0.039 \pm 0.002^{\mathrm{b}}$ \\
SFMT2 & $0.236 \pm 0.002^{\mathrm{c}}$ & $0.188 \pm 0.001^{\mathrm{d}}$ & $0.036 \pm 0.002^{\mathrm{c}}$ \\
SFMT3 & $0.269 \pm 0.002^{\mathrm{a}}$ & $0.193 \pm 0.002^{\mathrm{c}}$ & $0.028 \pm 0.002^{\mathrm{d}}$ \\
\hline
\end{tabular}

Mean \pm standard error based on duplicate values. Means within the same column with different superscript are significantly different using Duncans multiple range test at $\mathrm{p}<0.05$. Sample code as in Table 1 (UMT-unfermented blend).

Table 3. Vitamin contents of the maize-tigernut formulated blend samples.

\begin{tabular}{cccc}
\hline Sample code & $\begin{array}{c}\text { Vitamin B1 } \\
(\mathrm{mg} / 100 \mathrm{~g})\end{array}$ & $\begin{array}{c}\text { Vitamin B2 } \\
(\mathrm{mg} / 100 \mathrm{~g})\end{array}$ & $\begin{array}{c}\text { Vitamin A } \\
(\text { ug/100 g) }\end{array}$ \\
\hline $\mathrm{UMT}$ & $0.52 \pm 0.02^{\mathrm{c+*}}$ & $0.10 \pm 0.01^{\mathrm{d}}$ & $452.75 \pm 0.25^{\mathrm{e}}$ \\
$\mathrm{FMT}$ & $0.84 \pm 0.02^{\mathrm{a}}$ & $0.28 \pm 0.01^{\mathrm{a}}$ & $467.70 \pm 0.10^{\mathrm{b}}$ \\
$\mathrm{SFMT}_{1}$ & $0.67 \pm 0.02^{\mathrm{b}}$ & $0.18 \pm 0.01^{\mathrm{b}}$ & $472.60 \pm 0.10^{\mathrm{a}}$ \\
$\mathrm{SFMT}_{2}$ & $0.58 \pm 0.01^{\mathrm{c}}$ & $0.14 \pm 0.01^{\mathrm{c}}$ & $460.00 \pm 0.20^{\mathrm{d}}$ \\
$\mathrm{SFMT}_{3}$ & $0.63 \pm 0.04^{\mathrm{b}}$ & $0.20 \pm 0.01^{\mathrm{b}}$ & $464.05 \pm 0.25^{\mathrm{c}}$ \\
\hline
\end{tabular}

${ }^{*}$ Mean \pm standard error based on duplicate values. ${ }^{+}$Means within the same column with different superscript are significantly different using Duncans multiple range test at $\mathrm{P} \leq 0.05$.

$\mu \mathrm{g} / 100 \mathrm{~g}, 0.58 \mathrm{mg} / 100 \mathrm{~g}$ and $0.14 \mathrm{mg} / 100 \mathrm{~g}$ respectively was recorded for blend SFMT2. Statistical analysis showed a significant difference $(\mathrm{P} \leq 0.05)$ in the vitamin contents of the maize-tigernut blends.

\subsection{Mineral Contents of the Maize-Tigernut Formulated Blend Samples}

Table 4 shows the mineral composition of the maize-tigernut formulated blends. From the table, there is an observed variation in the effect of fermentation on the mineral content of the samples when compared with the unfermented sample (UMT). The phosphorus contents of all the fermented samples decreased with fermentation with the highest reduction observed in the spontaneously fermented sample FMT $(59.57 \mathrm{mg} / 100 \mathrm{~g})$ while the least reduction was observed in sample SFMT1 $(75.45 \mathrm{mg} / 100 \mathrm{~g})$ and also with highest Zinc content of 1.05 $\mathrm{mg} / 100 \mathrm{~g}$. The highest amount of calcium and iron contents of $17.17 \mathrm{mg} / 100 \mathrm{~g}$ and $22.82 \mathrm{mg} / 100 \mathrm{~g}$ respectively was recorded in blend SFMT2 while the least calcium $(14.05 \mathrm{mg} / 100 \mathrm{~g})$, magnesium $(1.57 \mathrm{mg} / 100 \mathrm{~g})$ and zinc $(0.59 \mathrm{mg} / 100 \mathrm{~g})$ contents was observed in the sample SFMT3. Statistical analysis of the blends revealed that the magnesium contents of SFMT1 and SFMT2, so also the iron content of FMT and SFMT1; zinc contents of the samples FMT and SFMT2 were not significantly different $(p>0.05)$ from each other. 
Table 4. Mineral contents ( $\mathrm{mg} / 100 \mathrm{~g}$ ) of the maize-tigernut formulated blend samples.

\begin{tabular}{cccccc}
\hline Sample code & Phosphorus & Calcium & Magnesium & Iron & Zinc \\
\hline UMT & $78.33 \pm 0.21^{\mathrm{a}}$ & $16.23 \pm 0.08^{\mathrm{b}}$ & $2.70 \pm 0.10^{\mathrm{a}}$ & $13.53 \pm 0.07^{\mathrm{c}}$ & $0.64 \pm 0.01^{\mathrm{c}}$ \\
FMT & $59.57 \pm 0.07^{\mathrm{d}}$ & $17.20 \pm 0.05^{\mathrm{a}}$ & $2.75 \pm 0.04^{\mathrm{a}}$ & $17.27 \pm 0.08^{\mathrm{b}}$ & $0.81 \pm 0.02^{\mathrm{b}}$ \\
SFMT1 & $75.45 \pm 0.05^{\mathrm{b}}$ & $15.38 \pm 0.07^{\mathrm{c}}$ & $2.47 \pm 0.01^{\mathrm{b}}$ & $17.28 \pm 0.06^{\mathrm{b}}$ & $1.05 \pm 0.04^{\mathrm{a}}$ \\
SFMT2 & $73.67 \pm 0.69^{\mathrm{c}}$ & $17.17 \pm 0.07^{\mathrm{a}}$ & $2.40 \pm 0.03^{\mathrm{b}}$ & $22.82 \pm 0.06^{\mathrm{a}}$ & $0.76 \pm 0.05^{\mathrm{b}}$ \\
SFMT3 & $74.42 \pm 0.08^{\mathrm{c}}$ & $14.05 \pm 0.05^{\mathrm{d}}$ & $1.57 \pm 0.03^{\mathrm{c}}$ & $13.70 \pm 0.03^{\mathrm{c}}$ & $0.59 \pm 0.04^{\mathrm{c}}$ \\
\hline
\end{tabular}

${ }^{*}$ Mean \pm standard error based on duplicate values.

\subsection{Sensory Evaluation of the Maize-Tigernut Formulated Blend Samples}

Table 5 shows the results of the sensory evaluation of the maize-tigernut formulated weaning blend among 20 untrained panelists made up of nursing mothers. The weaning blend fermented using the combined starter (SFMT3) had the highest rating in terms of the color with a mean score of 5.90 while sample SFMT2 was rated best in terms of the texture (5.40) and taste (6.10) whereas, the spontaneously fermented sample (FMT) had the least of ratings in all sensory attributes. Overall, blend SFMT2 had the highest acceptability rating of 6.00, statistically the starter fermented blends were significantly different $(\mathrm{P} \leq 0.05)$ from the spontaneously fermented blend (FMT).

\subsection{Biological Evaluation of Formulated and Standard Weaning Blends}

Table 6 shows the result of biological evaluation of the formulated blends over the 28 days of feeding trials. The highest mean weight gain $(6.77 \mathrm{~g})$ and mean feed intake $(19.49 \mathrm{~g})$ was observed in the group that fed on the commercially available weaning food (Nutrend) while among the formulated blends, the highest was observed in blend SFMT2 with mean weight gain of $5.46 \mathrm{~g}$ and mean feed intake of $18.71 \mathrm{~g}$. The highest mean feed conversion ratio (FCR) was recorded in blend SFMT1 (5.42) and the least value (3.31) recorded in Nutrend fed group. The statistical analysis shows that the mean weight gain, mean feed intake and mean FCR of the groups were not significantly different $(P>0.05)$ from each other. However, highest mean protein efficiency ratio (PER) of 3.65 was observed for blend SFMT2 which is significantly different $(\mathrm{P}<0.05)$ from both the positive (CAF) and negative (Nutrend) controls.

\subsection{Haematological Analysis of the Albino Rats}

Table 7 shows the results of hematological analysis of the albino rats fed with the experimental weaning diets for the duration of 28 days. The SFMT3 group fed had the least value $\left(6.95 \times 10^{6} / \mathrm{mm}^{3}\right)$ for the Red Blood Cell (RBC) count while the highest count $\left(9.50 \times 10^{6} / \mathrm{mm}^{3}\right)$ was observed in the SFMT1 group. Also, the White blood cell (WBC) count was observed to be highest in the group fed with the blend fermented using Lactobacillus plantarum U2A (SFMT2) as 
Table 5. Sensory evaluation of the maize-tigernut formulated blends.

\begin{tabular}{cccccc}
\hline Sample code & Color & Texture & Taste & Flavor & Overall acceptability \\
\hline FMT & $5.30 \pm 0.213^{\mathrm{a}}$ & $4.50 \pm 0.167^{\mathrm{b}}$ & $4.00 \pm 0.258^{\mathrm{b}}$ & $4.80 \pm 0.20^{\mathrm{c}}$ & $4.30 \pm 0.26^{\mathrm{b}}$ \\
SFMT1 & $5.60 \pm 0.16^{\mathrm{a}}$ & $4.70 \pm 0.15^{\mathrm{b}}$ & $5.60 \pm 0.16^{\mathrm{a}}$ & $6.30 \pm 0.23^{\mathrm{a}}$ & $5.60 \pm 0.16^{\mathrm{a}}$ \\
SFMT2 & $5.60 \pm 0.16^{\mathrm{a}}$ & $5.40 \pm 0.16^{\mathrm{a}}$ & $6.10 \pm 0.18^{\mathrm{a}}$ & $6.30 \pm 0.26^{\mathrm{a}}$ & $6.00 \pm 0.14^{\mathrm{a}}$ \\
SFMT3 & $5.90 \pm 0.23^{\mathrm{a}}$ & $5.20 \pm 0.20^{\mathrm{a}}$ & $5.70 \pm 0.21^{\mathrm{a}}$ & $5.60 \pm 0.16^{\mathrm{b}}$ & $5.50 \pm 0.17^{\mathrm{a}}$ \\
\hline
\end{tabular}

${ }^{*}$ Mean \pm standard error based on ten replicates.

Table 6. Biological evaluation of formulated and standard weaning blends.

\begin{tabular}{ccccccc}
\hline $\begin{array}{c}\text { Experimental } \\
\text { weaning diet }\end{array}$ & Initial weight (g) & $\begin{array}{c}\text { Weight at } \\
\text { day 28 }(\mathrm{g})\end{array}$ & $\begin{array}{c}\text { mean weight } \\
\text { gain }(\mathrm{g})\end{array}$ & $\begin{array}{c}\text { Mean feed } \\
\text { intake }(\mathrm{g})\end{array}$ & Mean FCR & Mean PER \\
\hline FMT & $24.65 \pm 1.28^{\mathrm{a}}$ & $66.77 \pm 0.35^{\mathrm{c}}$ & $4.64 \pm 0.43^{\mathrm{a}}$ & $17.16 \pm 0.89^{\mathrm{a}}$ & $4.22 \pm 0.66^{\mathrm{a}}$ & $3.40 \pm 0.31^{\mathrm{ab}}$ \\
SFMT1 & $26.64 \pm 1.07^{\mathrm{a}}$ & $70.41 \pm 0.94^{\mathrm{d}}$ & $4.92 \pm 0.76^{\mathrm{a}}$ & $17.94 \pm 1.26^{\mathrm{a}}$ & $5.42 \pm 1.63^{\mathrm{a}}$ & $3.42 \pm 0.54^{\mathrm{ab}}$ \\
SFMT2 & $24.00 \pm 0.47^{\mathrm{a}}$ & $73.14 \pm 0.62^{\mathrm{c}}$ & $5.46 \pm 0.74^{\mathrm{a}}$ & $18.71 \pm 1.06^{\mathrm{a}}$ & $4.27 \pm 0.83^{\mathrm{a}}$ & $3.65 \pm 0.51^{\mathrm{a}}$ \\
SFMT3 & $25.80 \pm 1.41^{\mathrm{a}}$ & $71.89 \pm 0.38^{\mathrm{cd}}$ & $5.16 \pm 0.48^{\mathrm{a}}$ & $18.69 \pm 0.96^{\mathrm{a}}$ & $4.28 \pm 0.71^{\mathrm{a}}$ & $3.36 \pm 0.31^{\mathrm{ab}}$ \\
Nutrend & $26.21 \pm 0.46^{\mathrm{a}}$ & $87.21 \pm 0.50^{\mathrm{a}}$ & $6.77 \pm 0.80^{\mathrm{a}}$ & $19.49 \pm 1.08^{\mathrm{a}}$ & $3.31 \pm 0.48^{\mathrm{a}}$ & $2.29 \pm 0.25^{\mathrm{b}}$ \\
CAF & $25.20 \pm 0.88^{\mathrm{a}}$ & $79.48 \pm 0.74^{\mathrm{b}}$ & $6.09 \pm 0.71^{\mathrm{a}}$ & $18.39 \pm 1.29^{\mathrm{a}}$ & $3.42 \pm 0.42^{\mathrm{a}}$ & $2.30 \pm 0.32^{\mathrm{b}}$ \\
\hline
\end{tabular}

Mean \pm standard error based on three replicates. Means within the same column with different superscript are significantly different using Duncans multiple range test at $\mathrm{p}<0.05$. Key: FCR: -Feed Conversion Ratio; PER: -Protein Efficiency Ratio; CAF: -Conventional Available Feed.

Table 7. Haematological analysis of experimental animal group.

\begin{tabular}{|c|c|c|c|}
\hline Experimental diet Group & Red blood cell $(\mathrm{RBC}) \times 10^{6} / \mathrm{mm}^{3}$ & White blood cell $(\mathrm{WBC}) \times 10^{3} / \mathrm{mm}^{3}$ & Packed cell volume (PCV) \% \\
\hline FMT & $8.75 \pm 0.25^{\mathrm{ab}+^{*}}$ & $6.78 \pm 0.09^{\mathrm{bc}}$ & $38.67 \pm 0.33^{\mathrm{b}}$ \\
\hline SFMT1 & $9.50 \pm 0.12^{\mathrm{a}}$ & $6.90 \pm 0.06^{\mathrm{ab}}$ & $34.67 \pm 0.67^{\mathrm{c}}$ \\
\hline SFMT2 & $8.83 \pm 0.33^{\mathrm{ab}}$ & $7.03 \pm 0.03^{\mathrm{ab}}$ & $40.00 \pm 0.58^{\mathrm{b}}$ \\
\hline SFMT3 & $6.95 \pm 0.06^{\mathrm{d}}$ & $7.03 \pm 0.09^{\mathrm{ab}}$ & $38.33 \pm 1.20^{\mathrm{b}}$ \\
\hline Nutrend & $7.78 \pm 0.32^{\mathrm{c}}$ & $7.22 \pm 0.12^{\mathrm{a}}$ & $43.00 \pm 0.58^{\mathrm{a}}$ \\
\hline CAF & $8.17 \pm 0.23^{\mathrm{bc}}$ & $6.44 \pm 0.21^{\mathrm{c}}$ & $39.33 \pm 0.88^{\mathrm{b}}$ \\
\hline $\begin{array}{c}\text { Rat Haematologic reference } \\
\text { ranges }\end{array}$ & $6.76-9.75$ & $6.6-12.6$ & $37.6-50.6$ \\
\hline
\end{tabular}

${ }^{*}$ Mean \pm standard error based on triplicate values. ${ }^{+}$Means within the same column with different superscript are significantly different using Duncans multiple range test at $\mathrm{P} \leq 0.05$.

well as the blend fermented using combined starter (SFMT3), with a value of $7.03 \times 10^{3} / \mathrm{mm}^{3}$ while the least WBC $\left(6.78 \times 10^{3} / \mathrm{mm}^{3}\right)$ was recorded for the group fed with the spontaneously fermented blend (FMT). Statistical analysis of the white blood cell count showed that SFMT1, SFMT2 and SFMT3 fed groups were not significantly different $(\mathrm{p}<0.05)$ from each other but were significantly different from FMT, Nutrend and Conventional animal fed groups.

The least packed cell volume (PCV) value of $34.67 \%$ and highest value of $40.00 \%$ were observed in the groups fed with sample SFMT1 and sample SFMT2 respectively. Packed cell volume (PCV) of group one (FMT), group three (SFMT2), group four (SFMT3) and group six (conventional animal feed) were 
not significantly different $(\mathrm{P} \leq 0.05)$ from each other but different from the PCV of group two (SFMT1) and group five (Nutrend). Generally, the RBC, WBC and PCV of the trial groups were within the rat haematologic reference ranges.

\section{Discussion}

The observed lower moisture contents of the fermented products will improve the storage period or keeping quality of the product because low moisture content would prevent the growth of mould and reduce moisture dependant biochemical reactions [43]. Higher protein contents of Lactobacillus fermented blends compared to the spontaneously fermented blend may be due to an increase in the proteolytic activities of the starters during fermentation which might have resulted in increased production of essential amino acids, an observation similar to that of Saleh et al. [44] and Apaliya et al. [45]. Thus improve in the protein quality of the starter products [46] resulting in an upgraded nutritious products which can prevent Protein Energy Malnutrition in developing countries. The higher ash contents recorded in starter fermented blends compare to the spontaneously fermented blend is an indication of increased mineral contents of the starter developed blends. Similar observation was reported by Wakil and Alagbe [28] on a related study on tigernut fortified weaning food. The starter fermented food formulations can serve as a very good source of energy with values ranging from 435.14 to $456.84 \mathrm{kcal} / 100 \mathrm{~g}$ when compared with commercial and conventional feeds for babies and animals, although the recommended daily allowance (RDA) for infants is $3000 \mathrm{kcal}$ [47]. However higher energy value than those recorded in this study was recorded by Shiriki et al. [48] in their findings on nutritional evaluation of a complementary food formulation.

The higher mineral contents recorded in the SFMT2 sample could be of nutritional advantage to the weaning infants as minerals play important roles in body metabolism. The high calcium contents helps in the regulation of muscle contractions and transmission of nerve impulses, bone and teeth development [49] while the iron helps in heamoglobin formation. This could also be the reason for higher PCV recorded for this sample. This increase in the iron content also agrees with the findings of Oyarekua [50]. Iron deficiency can impair physical and cognitive development and immune response.

The improvement in organoleptic properties observed with the use of starter fermentation is similar to the report of Wakil and Kazeem [19]. However findings indicated that differences in sensorial properties were not significantly $(p>$ 0.05 ) associated with the type of starter (lactic acid bacteria) used in the fermentation. This variation may be due to the subjective nature of sensory analysis using human beings. Generally, LABs contribute to the aroma and taste of fermented products [51] by acidifying food and gives it a tangy lactic acid taste.

The animal group fed with SFMT2 had the highest weight by 28 days (73.14 g), mean weight gain $(5.46 \mathrm{~g})$, mean feed intake $(18.71 \mathrm{~g})$ and mean protein efficiency ratio, PER (3.65). However, all the PER values including that of controls 
(2.30) were higher than the value of 2.10 recommended by the Protein Advisory Group (PAG) for complementary foods. The higher PER and FCR values of fermented food products could be due to utilization of the increased protein and micronutrients from the tigernut supplement by the experimental animals. An observations similar with earlier reports of significant increase in PER in rats as a result of improved nutritional composition [48] [52]. The Red Blood Cell (RBC), White Blood Cell (WBC) and Packed Cell Volume (PCV) of the trial groups were within the rat haematologic reference ranges.

\section{Conclusion}

In Conclusion, blend SFMT2 (L. plantarum U2A fermented blend) has higher nutritional contents and gives the best performance after rat feeding trials, therefore, can be used as starter in weaning food development.

\section{Conflicts of Interest}

The authors declare no conflicts of interest regarding the publication of this paper.

\section{References}

[1] Gdalevich, M., Mimouni, D. and Mimouni, M. (2001) Breast-Feeding and the Risk of Bronchial Asthma in Childhood: A Systematic Review with Meta-Analysis of Prospective Studies. Journal of Pediatrics, 139, 261-266. https://doi.org/10.1067/mpd.2001.117006

[2] Koch, A., Mølbak, K., Homøe, P., Sørensen, P., Hjuler, T., Olesen, M.E., Pejl, J., Pedersen, F.K., Olsen, O.R. and Melbye, M. (2003) Risk Factors for Acute Respiratory Tract Infections in Young Greenlandic Children. American Journal of Epidemiology, 158, 374-384. https://doi.org/10.1093/aje/kwg143

[3] Van Odijk, J.V., Kull, I., Borres, M.P., Brandtzaeg, P., Edberg, U., Kuitunen, M., Olsen, S.F., Skerfving, S., Sundell, J. and Wille, S. (2003) Breastfeeding and Allergic Disease: A Multi-Disciplinary Review of the Literature (1966 to 2001) on the Mode of Early Feeding in Infancy and Its Impact on Later Atopic Manifestations. Allergy, 58, 833-843. https://doi.org/10.1034/j.1398-9995.2003.00264.x

[4] Black, R.E., Allen, L.H., Bhutta, Z., Caulfield, L.E., De Onis, M., Ezzati, M., Mathers, C. and Rivera, J. (2008) Maternal and Child Undernutrition: Global and Regional Exposures and Health Consequences. The Lancet, 371, 243-260. https://doi.org/10.1016/S0140-6736(07)61690-0

[5] American Academy of Pediatrics (2012) Breastfeeding and the Use of Human Milk. Pediatrics, 129, 827. https://doi.org/10.1542/peds.2011-3552

[6] World Health Organization (2012) Nutrient Adequacy of Exclusive Breastfeeding for the Term Infant during the First Six Months of Life. Geneva.

[7] Kramer, M.S. and Kakuma, R. (2001) The Optimal Duration of Exclusive Breastfeeding: A Systematic Review. Geneva, World Health Organization, Document WHO/NHD/01.08-WHO/FCH/CAH/01.23.

[8] World Health Organization (WHO) (2002) Global Strategy for Infant and Young Child Feeding. WH/A55/2002/REC/1 Annex 2, Geneva.

[9] Harris, G. (2000) Developmental, Regulatory and Cognitive Aspects of Feeding Disorders. In: Southall, A. and Schwartz, A., Eds., Feeding Problems in Children, 
Radcliffe Medical Press, Oxford, UK.

[10] Fewtrell, M., Lucas, A. and Morgan, J.B. (2003) Factors Associated with Weaning in Full Term and Pre-Term Infants. ADC Fetal \& Neonatal Edition, 88, F296-F301. https://doi.org/10.1136/fn.88.4.F296

[11] Dewey, K.G. and Brown, K.H. (2003) Update on Technical Issues Concerning Complementary Feeding of Young Children in Developing Countries and Implications for Intervention Programs. Food and Nutrition Bulletin, 24, 5-28. https://doi.org/10.1177/156482650302400102

[12] Pelto, G.H., Levitt, E. and Thairu, L. (2003) Improving Feeding Practices: Current Patterns, Common Constraints, and the Design of Interventions. Food Nutrition Bulletin, 24, 24-82. https://doi.org/10.1177/156482650302400104

[13] World Health Organization (WHO) (2006) Multicentre Growth Reference Study. Acta Paediatrica, 450, 1-87.

[14] Onofiok, N.O. and Nnanyelugo, D.O. (1998) Weaning Foods in West Africa: Nutritional Problems and Possible Solutions. Food and Nutrition Bulletin, 19, 27-33. https://doi.org/10.1177/156482659801900105

[15] Ndukwe, O. (2006) Production of Special Enriched Ogi Powder Using Sorghum, Soyabean, Ginger, Cloves and Chilki Pepper. Department of Food Science and Technology, Federal Polytechnic Bauchi.

[16] Krebs, N.F and Westcott, J. (2002) Zinc and Breastfed Infants: If and When Is There a Risk of Deficiency? Journal of Advances in Experimental Medicine and Biology, 503, 69-75. https://doi.org/10.1007/978-1-4615-0559-4_7

[17] Neumann, C., Harris, D.M. and Rogers, L.M. (2002) Contribution of Animal Source Foods in Improving Diet Quality and Function in Children in the Developing World. Nutrition Research Journal, 22, 193-220. https://doi.org/10.1016/S0271-5317(01)00374-8

[18] Onilude, A.A., Sanni, A.I. and Ighalo, M.I. (2004) Process Upgrade and the Microbiological, Nutritional and Consumer Acceptability of Infant Weaning Food from Fermented Composite Blends of Cereals and Soybean. Journal of Food, Agriculture and Environment, 2, 64-68.

[19] Wakil, S.M. and Kazeem, M.O. (2012) Quality Assessment of Weaning Food Produced from Fermented Cereal-Legume Blends Using Starters. International Journal of Food Research, 19, 1679-1685.

[20] Sanoussi, A.F., Dansi, A., Bokossa-yaou, I., Dansi, M., Egounlety, M., Sanni, L.O. and Sanni, A. (2013) Formulation and Biochemical Characterization of Sweet Potato (Ipomoea batatas) Based Infant Flours Fortified with Soybean and Sorghum Flours. International Journal of Current Microbiology and Applied Science, 2, 22-34.

[21] Afoakwa, E.O. (1996) Storage Characteristics and Quality Evaluation of Cowpea-Fortified Traditional Foods. B.Sc. Dissertation, Department of Nutrition and Food Science, University of Ghana, Legon-Accra.

[22] Onilude, A.A., Sanni, A.I. and Ighalo, M.I. (1999) Effect of Process Improvement on the Physicoshemical Properties of Infant Weaning Food from Fermented Composite Blends of Cereal and Soyabeans. Plant Foods for Human Nutrition, 54, 239-250. https://doi.org/10.1023/A:1008105521196

[23] Sanni, A.I., Onilude, A.A. and Ibidapo, O.F. (1999) Physico-Chemical Characteristics of Weaning Food Formulated from Different Blends of Cereal and Soybean. Zlebensm unters Forsch, 208, 221-224. https://doi.org/10.1007/s002170050407 
[24] Sefa-Dedeh, S. and Cornelius, B. (2000) The Microflora of Dietary Bulk as a Limiting Factor for Nutrient Intake in Fermented Nixtamalized Corn. Presented at the Annual Pre-School Children. A Problem Description. Journal Meeting of the Institute of Food Technologists, and Tropical Pediatrics, 27, 68-73.

[25] Sefa-Dedeh, S., Sakyi-Dawson, E., Afoakwa, E.O., Andoh-Kumi, K. and Tawo-Debrah, K. (2001) Effect of Drying Method, Packaging Material and Storage on the Quality of Cowpea-Based Weaning Foods. Annual Meeting of the Institute of Food Technologists, New Orleans, 25-29 June 2001.

[26] Mbata, T.I., Ikenebomeh, M.J. and Ezeibe, S. (2009) Evaluation of Mineral Content and Functional Properties of Fermented Maize (Generic and Specific) Flour Blended with Bambara Groundnut (Vigna subterranean). African Journal of Food Science, 3, 107-112.

[27] Emmanuel-Ikpeme, C.A., Ekpeyoung, I.O. and. Igile, G.O. (2012) Nutritional and Sensory Characteristics of an Infant Food Based on Soybean Seeds (Glycine max) and Tigernut Tubers (Cyperus esculenta). British Journal of Applied Science and Technology, 2, 356-366. https://doi.org/10.9734/BJAST/2012/1341

[28] Wakil, S.M. and Alagbe, C.E. (2017) Effect of Processing Methods on Microbiological and Nutritional Qualities of Tigernut-Fortified Weaning Food. Advances in Food Sciences, 39, 48-56.

[29] Belewu, M.A. and Abodunrin, O.A. (2006) Preparation of Kunnu from Unexploited Rich Food Source: Tigernut (Cyperus esculentus). World Journal of Dairy and Food Sciences, 1, 19-21.

[30] Belewu, M.A. and Belewu, K.Y. (2007) Comparative Physio-Chemical Evaluation of Tigernut, Soybean and Coconut Milk Sources. International Journal of Agriculture and Biology, 9, 785-787.

[31] Ade-Omowaye, B.I., Akinwande, B.A., Bolarinwa, I.F. and Adebiyi, A.O. (2008) Evaluation of Tigernut (Cyperus esculentus) Wheat Composite Flour and Bread. African Journal of Food Science, 2, 87-91.

[32] Ukwuru, M.U., Ibeneme, C.L. and Agbo, G.I. (2011) New Product Development from Tigernut (Cyperus esculentus) and Their Sensory, Proximate and Microbiological Evaluation. Pakistan Journal of Nutrition, 10, 101-105. https://doi.org/10.3923/pjn.2011.101.105

[33] Wakil, S.M., Ayenuro, O.T. and Oyinlola, K.A. (2014) Microbiological and Nutritional Assessment of Starter-Developed Fermented Tigernut Milk. Food and Nutrition Sciences, 5, 495-506. https://doi.org/10.4236/fns.2014.56059

[34] Malleshi, N.G., Daodu, M.A. and Chandrasekhar, M.L. (1989) Development of Weaning Food Formulations Based on Malting and Roller Drying of Sorghum and Cowpea. International Journal of Food science and Technology, 24, 511-519. https://doi.org/10.1111/j.1365-2621.1989.tb00674.x

[35] Livingstone, A.S., Fengi, J.J. and Malleshi, G.N. (1993) Development and Nutritional Quality Evaluation of Weaning Foods Based on Malted, Popped and Roller Dried Wheat and Chickpea. International Journal of Food Science Technology, 28, 35-43. https://doi.org/10.1111/j.1365-2621.1993.tb01249.x

[36] Rodriguez-Tudela, J.L., Chrysanthou, E., Evangelia, P., Juan, M., David, W.D. and Manuel, C.E. (2003) Inter-Laboratory Evaluation of Haemocytometer Method of Inoculums Preparations for Testing Antifungal Susceptibility of Filamentous Fungi. Journal of Clinical Microbiology, 41, 5236. https://doi.org/10.1128/JCM.41.11.5236-5237.2003

[37] AOAC (2012) Official Methods of Analysis. 19th Edition, Association of Official 
Analytical Chemists, Arlington, 806-842.

[38] AOAC (2005) Official Methods of Analysis. 18th Edition, Association Official Analytical Chemists, Washington DC, 18.

[39] Sanchez-Alonso, F. and Lachica, M. (1987) Seasonal Trends in the Elemental Content of Plum Leaves. Communications in Soil Science and Plant Analysis Journal, 18, 31-44. https://doi.org/10.1080/00103628709367801

[40] Wakil, S.M. and Alao, O.K. (2013) Microbiological and Nutritional Qualities of Moringa oleifera Supplemented and Fermented Weaning Blends. Journal of Science Research, 12, 73-85.

[41] Addass, P.A., Midau, A., Perez, I.K.A. and Magaji, M.Y. (2010) The Effect of Type and Levels of Animal Protein Supplements on the Growth Rate of Rats. Agriculture and Biology Journal of North America, 1, 841-844. https://doi.org/10.5251/abjna.2010.1.5.841.844

[42] Bull, B.S., Koepke, J.A., Simson, E. and Assendelft, O.W. (2000) Procedure for Determining Packed Cell Volume by the Hematocrit Method. 3rd Edition, NCCLS Publication H7-A3. Wayne, Pennsylvania.

[43] Onimawo, I.A. and Akubor, P.I. (2012) Food Chemistry (Integrated Approach with Biochemcial background). 2nd Edition, Joytal Printing Press, Agbowo.

[44] Saleh, A.S., Zhang, Q., Chen, J. and Shen, Q. (2013) Millet Grains: Nutritional Quality, Processing, and Potential Health Benefits. Comprehensive Reviews in Food Science and Food Safety, 12, 281-295. https://doi.org/10.1111/1541-4337.12012

[45] Apaliya, M.T., Kwaw, E., Tchabo, W., Sackey, A.S. and Boateng, N.A.S. (2017) The Use of Lactic Acid Bacteria as Starter Culture and Its Effect on the Proximate Composition and Sensory Acceptability of Millet Beverage. International Journal of Innovative Food Science and Technology, 1, 1-8. https://doi.org/10.25218/ijifst.2017.01.001

[46] Holzapfel, W.H. (2002) Appropriate Starter Culture Technologies for Small-Scale Fermentation in Developing Countries. International Journal of Food Microbiolo$g y$, 75, 197-212. https://doi.org/10.1016/S0168-1605(01)00707-3

[47] Gaman, P.M. and Sherrington, K.B. (1990) The Science of Food. An Introduction to Food Science, Nutrition and Microbiology. 3rd Edition, Pergamon Press, Oxford, New York, 104-115.

[48] Shiriki, D., Igyor, M.A. and Gernah, D.I. (2015) Nutritional Evaluation of Complementary Food Formulations from Maize, Soybean and Peanut Fortified with $\mathrm{Mo}$ ringa oleifera Leaf Powder. Food and Nutrition Sciences, 6, 494-500. https://doi.org/10.4236/fns.2015.65051

[49] Cataldo, C.B., DeBruyne, L.K. and Whitney, E.N. (1999) Nutrition and Diet Therapy Principles and Practise. 5th Edition, Wadsworth Publishing Company and International Thompson Publishing Company, Belmont, 35-204.

[50] Oyarekua, M.A. (2011) Evaluation of the Nutritional and Microbiological Status of Co-Fermented Cereals/Cowpea "Ogi”. Agriculture and Biology Journal of North America, 2, 61-73. https://doi.org/10.5251/abjna.2011.2.1.61.73

[51] Leroy, F. and De Vuyst, L. (2004) Lactic Acid Bacteria as Functional Starter Cultures for the Food Fermentation Industry. Trends in Food Science and Technology, 15, 67-78. https://doi.org/10.1016/j.tifs.2003.09.004

[52] Oluwamukomi, M.O., Eleyemi, A.F., Enujiugha, V.N. and Atofarati, S.O. (2003) Nutritional, Physico-Chemical and Sensory Evaluation of Sorghum and Cowpea Based Complementary Formulations. Nigerian Food Journal, 21, 11-17. 